\title{
Design and Development of 1.5KW Pelton Wheel Turbine
}

\author{
Eimad Eldin Elhadi Musa ${ }^{1}$, Mohamed Ahmed Ibrahim Mohamed ${ }^{2}$
}

\begin{abstract}
This paper aims to represent a pelton wheel turbine that designed and fabricated in Omdurman Islamic University, faculty of engineering Sciences. The pelton wheel is designed using empirical formulae and its model is tested for the purpose to get its performance characteristics. The main geometric parameters which determined in this work are runner diameter, bucket size and nozzle diameter and dimension of other mechanical parts. The results which obtained by this design procedure are compared with that in available literature and they are acceptable.
\end{abstract}

Key words: Pelton wheel turbine, nozzle, high head hydro-power site.

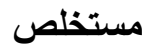

هذه الورقة تهدف لعرض التصميم الأساسي لعجلة توربينة بلتون التي تم تصميمها و تصنيعها في جامعة

أم درمان الإسلامية كلية العلوم الهندية . تم تصميم عجلة بلتون باستخدام معادلات رياضية تجريبيه وقد تم تصنيع

نموذج لهذا التوربين. تم اختبار هذا النموذج بهذف ايجاد المنحنيات المميزة لاداءه. الابعاد الهندية الاساسية التي

تم ايجادها هي قطر الدوار، حجم الاقداح وابعادها ، قطر المنفث وكذلك كل الابعاد الخاصة بالاجزاء الميكانيكية.تمت مقارنة النتائج التي تم التوصل اليها بتلك المتوفرة في مراجعة المصادر فوجد توافق مقبول بين النتائج.

\section{Introduction}

\footnotetext{
${ }^{1}$ Aeronautical Engineering Department-Karary University-Sudan

${ }^{2}$ Department of Mechanical Engineering- Omdurman Islamic University-Sudan
} 
Design and Development of 1.5KW Pelton Wheel Turbine Eimad Eldin Elhadi Musa

Energy may exist in various forms. Hydraulic energy is that which produced by fluid. The fluid energy may be in the form of kinetic, pressure, potential, strain or thermal energy. A machine in which hydraulic energy is converted to mechanical energy is known as turbine. The most common turbines are Pelton wheel turbine, Francis turbine and propeller turbine. The Pelton usually used in high head hydro-power site [1].

Several types of hydraulic impulse turbines have been produced in the past, but the only one that has survived is the Pelton wheel, so called in honor of Lester Allen Pelton who contributed much to its development in the early gold-mining days in California [2]. Pelton was granted a patent in 1880 on an improved type of bucket, its principal feature being a splitter in the middle, since previously the bucket were merely cups. Later, W.A.D. Doble brought out the ellipsoidal bucket, which is the basis of the modern pelton wheel [3].

\section{Design Procedure}

The main design requirements are:-

The required output power $\mathrm{P}_{\mathrm{g}}=1.5 \mathrm{KW}$, Generator speed $\mathrm{Ng}=947.045 \mathrm{rpm}$ Generator efficiency $(\eta \mathrm{g})=0.8$, Mechanical efficiency $(\eta \mathrm{m})=0.85$

\subsection{Design of wheel}

The equations used to determine the different design parameters of wheel are collected in table (1).

Table (1) Equations used to calculate wheel design parameters $[1,4]$ 


\begin{tabular}{|c|c|}
\hline Design parameter & Equation \\
\hline Brake power of turbine & $B . P=\frac{P_{g}}{\eta_{g} \eta_{m}}$ \\
\hline Velocity of jet & $v_{1}=c_{v} \sqrt{2 g H}$ \\
\hline Velocity of bucket & $U=0.46 V_{1}$ \\
\hline $\begin{array}{l}\text { Total energy transferred to } \\
\text { the wheel }\end{array}$ & $E=\frac{U}{g}\left(V_{1}-U\right)(1-K \cos \theta)$ \\
\hline Required flow rate $(\mathrm{Q})$ & $Q=\frac{B . P}{\rho g E}$ \\
\hline Area of Nozzle & $A=\frac{Q}{V_{1}}$ \\
\hline Nozzle diameter & $D_{n}=\sqrt{A * \frac{4}{\pi}}$ \\
\hline $\begin{array}{l}\text { Pitch diameter of pelton } \\
\text { wheel }\end{array}$ & $D_{r u n}=\frac{60 U}{\pi * N_{t}}$ \\
\hline Number of buckets & NO.of $\quad$ bruckets $=0.5 \frac{D_{r u n}}{D_{n}}+15$ \\
\hline Bucket Dimensions & $\begin{array}{c}B=(4) D_{n} \quad C=(0.9) D_{n} \\
M=(1.1) D_{n} \quad L=(2.4) D_{n} \quad I=(1.2) D_{n}\end{array}$ \\
\hline
\end{tabular}

The final shape of designed bucket and wheel are shown in figures (1, 2 and 3). These figures show the main geometric parameters which calculated according to equations in table (1) 

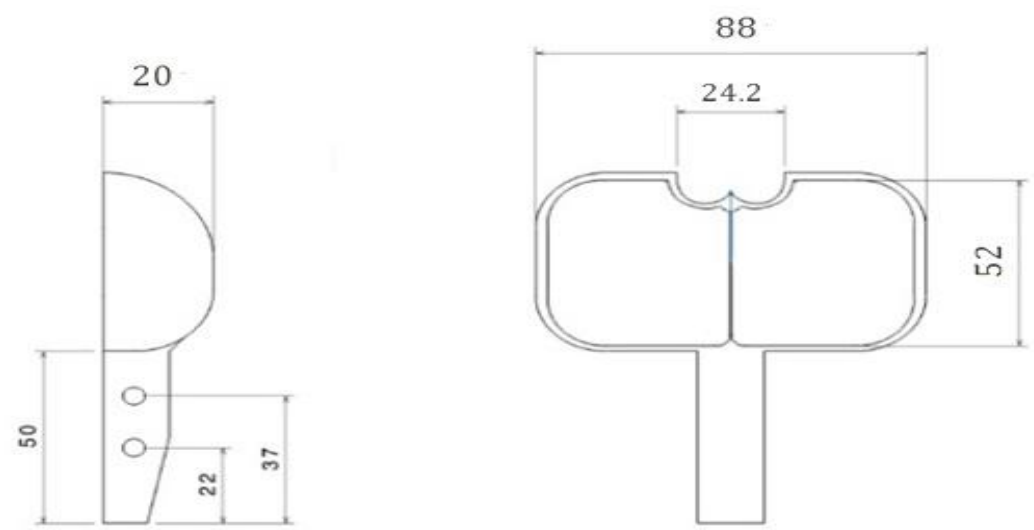

Figure (1): Front and Side View of the Bucket (all dimension in mm)
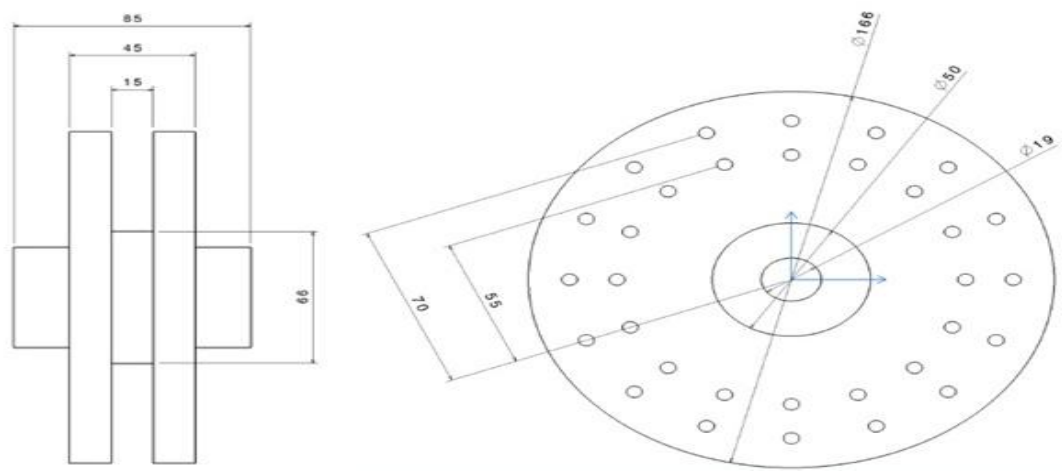

Figure (2): Front and Side View of the Wheel (all dimension in mm)
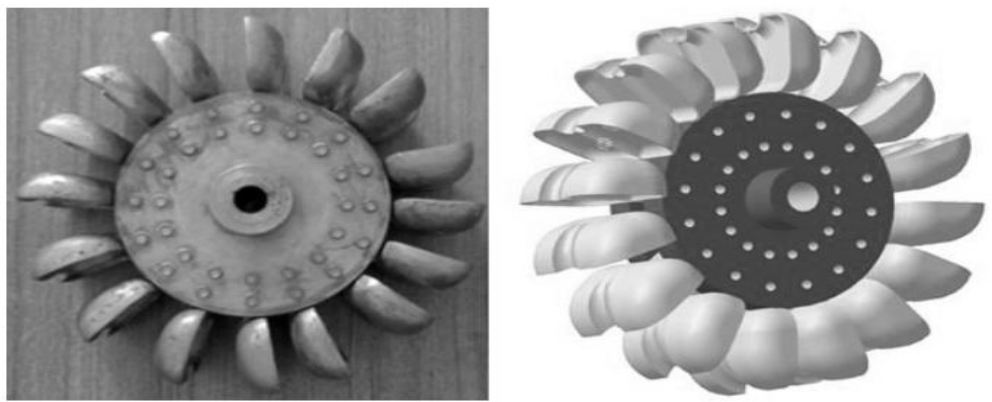

Figure (3): Three Dimension View of Pelton Runner 


\subsection{Design of the Shaft and Friction Brake}

For shaft the following equations are used to calculate its main dimension:

i- Force exerted upon the shaft:

$F_{s}=\frac{B p}{U}=\frac{\rho g Q E}{U}$

ii- Torque transmitted by the shaft (T):

$T=\frac{P * 60}{2 \pi N}$

ii- shaft material:

The shaft is made from mild steel with an allowable sheer stress of (42 $\mathrm{MPa}$ ). This material has ultimate shear stress $336 \mathrm{MPa}$ and a factor of safety as (8). This means that.

$\tau=\frac{\tau_{u}}{F . S .}=\frac{336}{8}=42 \mathrm{~N} / \mathrm{mm}^{2}$

iii- Maximum torque transmitted by the shaft:

$T \max =\frac{\pi}{16} * \tau * d^{3}$

We used a single block brake or shoe brake (figure (4)). All the geometric parameter for the brake is calculated using the following equations:

Torque transmitted by this brake is calculated:

$T_{B}=F_{t} * R$ 
Where:

$F_{t}=$ Tangential braking force $=\mu^{\prime} \cdot R_{\mathrm{N}}$

$\mu^{\prime}=\frac{4 \mu \sin \phi}{2 \phi+\sin 2 \phi}$

$R_{N}(X)=F_{t}(a)+P(l)=P(l)+\mu^{\prime} R_{N} a$

$R_{N}\left(x-\mu^{\prime} a\right)=P(l)$

$R_{N}=\frac{P(l)}{\left(x-\mu^{\prime} a\right)}$

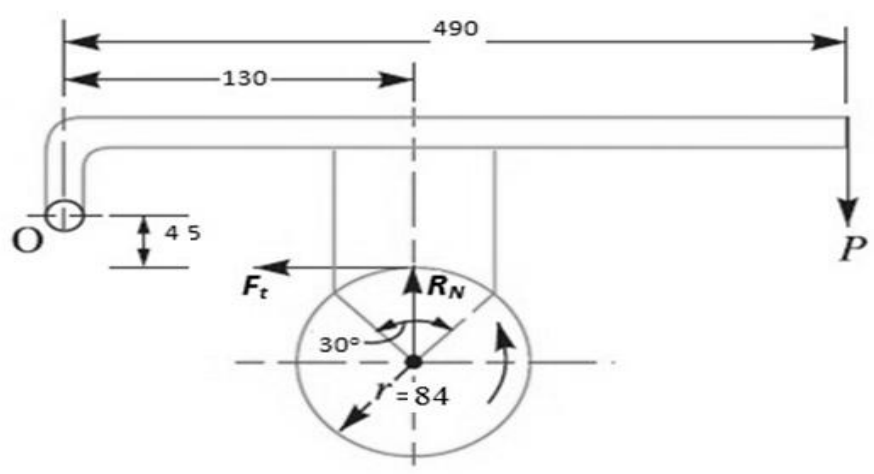

Figure (4): Dimensions of Single block brake (dimension in mm).

\section{Performance of Turbine}

For the purpose to get the performance of our designed turbine, an experimental test rig is built inside omdurman Islamic university. This rig is shown in figure (5) with pelton wheel turbine mounted on it. The main parameters that can be measured are: flow rate, rotational speed and output power. 


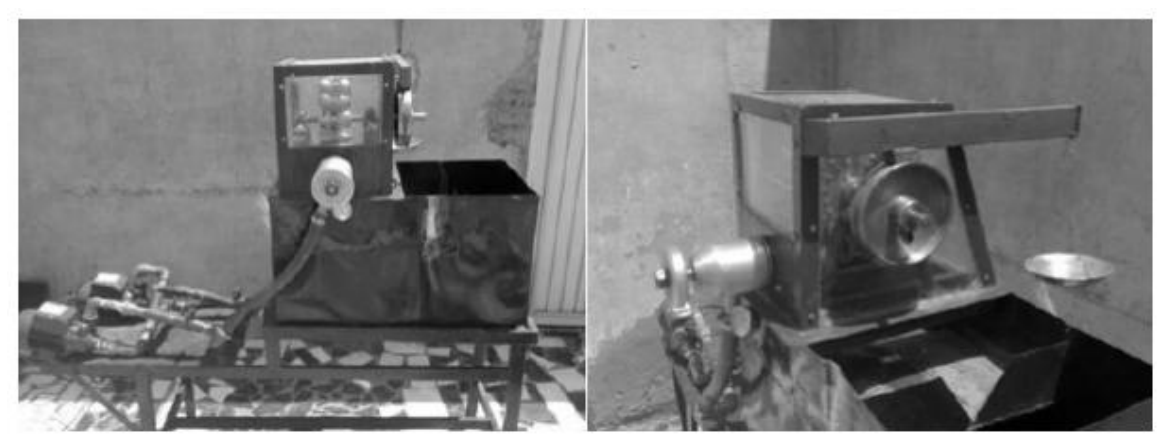

\section{Figure (5): Experimental Test Rig for Our Designed Pelton Wheel}

The performance curves for this pelton wheel turbine as predicted by using the manufactured rig are shown in figure (6). From these figures one can predict the different operating conditions for present turbine. Also one can notice that these figures are as that stander figures which are available in literature.

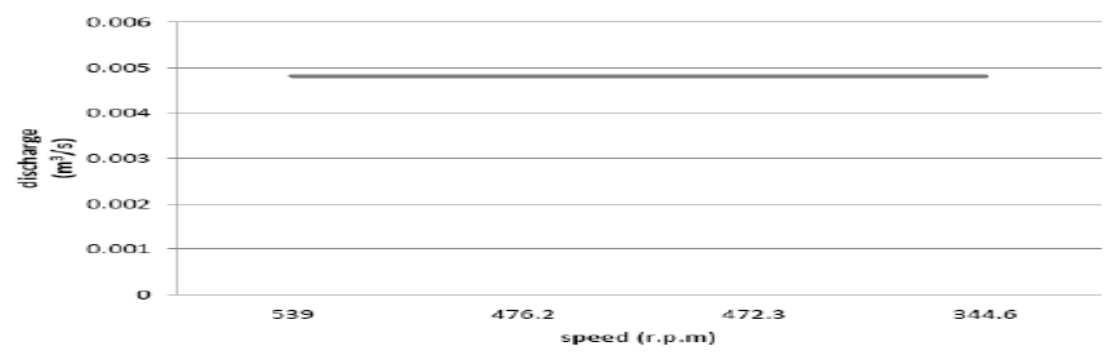

(a)

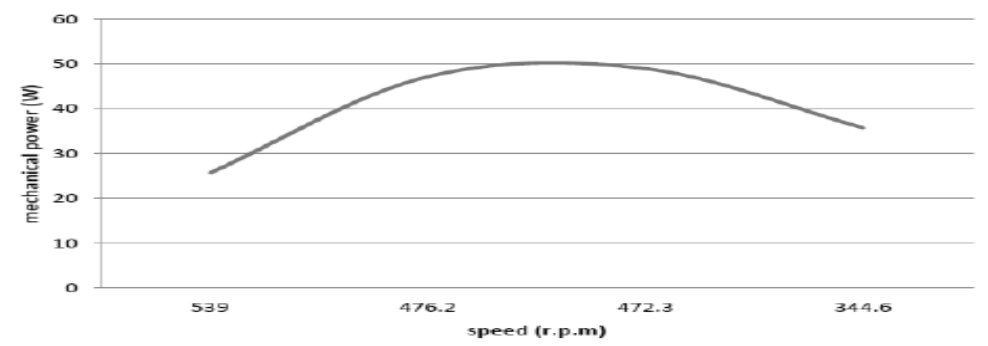

(b) 
Design and Development of 1.5KW Pelton Wheel Turbine Eimad Eldin Elhadi Musa

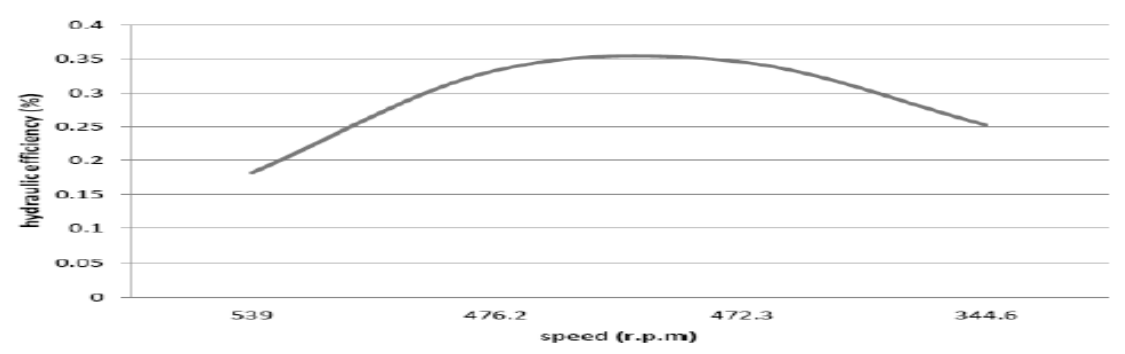

(c)

Figure (6): Performance Curves of the Designed Pelton Wheel a)

Discharge vs. Speed b) Mechanical power vs. speed c) Hydraulic

\section{Efficiency vs. Speed}

\section{Conclusion}

In this paper, we designed and manufactured pelton wheel turbine. The design methods depend on empirical formula found in the available literature. Some of important performance curves are predicted using experimental test rig which manufactured in omdurman Islamic university.

\section{Recommendations}

The recommendations are summarized as follow:

1- In order to fulfill the requirement of electricity in our country, hydroelectric projects are favorable to be implemented.

2- Pelton wheel turbine is an impulse turbine which need site with high head to obtain the high pressure on the buckets. But unfortunately we have in Sudan a few locations have this specification, And the suitable location for a real Pelton wheel turbine is [Marrah Mountains] that rises up to $(3,000$ $\mathrm{m})$, or in the petroleum pipe line before inter Port sudan. 
3- The experimental test rig which made in this project can be used as educational apparatus in the different local universities.

\section{References}

[1] MEIKTILA, Basic Design of Pelton Wheel Turbine.

[2] International Historic Mechanical Engineering Landmark.

[3] Daugherty- Franzini, Fluid Mechanics with Engineering Applications, seventh edition, McGraw-Hill Book Company.

[4] R.S.KHURMI and J.K.GUPTA, A Textbook of Machine Design (S.I. UNITS), first multicolor edition EURASIA PUBLISHING HOUSE (PVT.) LTD, 2005.

[5] R.K.RAJPUT, A textbook of Fluid Mechanics and Hydraulic Machines, in S.I. UNITS, Third Edition 2006. 